\title{
A Physiological and Genetical Study for the Effect of Gamma Irradiation on Moringa olefiera Lam.
}

\author{
Hanan M. Mansour ${ }^{(1)}$, Nahla Hamideldin ${ }^{(1) \#}$, Fatthy M. Abdel-tawab ${ }^{(2)}$, Eman M. \\ Fahmy ${ }^{(2)}$, Huda El-Demerdach ${ }^{(1)}$ and Mohamed H. Amar $^{(3)}$ \\ ${ }^{(1)}$ Natural Products Research Department, National Center for Radiation Research \\ and Technology, Atomic Energy Authority (AEA), Cairo, Egypt, P.O.Box 29 Nasr City, \\ Cairo, Egypt; ${ }^{(2)}$ Genetics Department, Faculty Agriculture, Ain Shams University, \\ Shoubra El Kheima, Egypt; ${ }^{(3)}$ Egyptian Deserts Gene Bank, Desert Research Center, \\ Cairo, Egypt.
}

\begin{abstract}
CEEDS of Moringa oleifera plant were exposed to different gamma irradiation doses; 0,20 , $\checkmark 40$ and 60Gy. Effects of gamma irradiation on a number of vegetative, physiological and molecular characters were studied. The vegetative characters were studied for two seasons, the highest values for the studied characters were often observed at the dose of 40Gy ( 8 characters) then at the dose of $60 \mathrm{~Gy}$ ( 4 characters). The physiological characters studied were total phenolic compounds contents, amino acid contents and antioxidant enzymes activity. Total phenols contents showed a significant increase in all used doses compared with the control. Amino acids content was affected widely by gamma doses, especially with 20 and 40Gy.The effect of gamma irradiation on the activity of five antioxidant enzymes (catalase, polyphenol oxidase, peroxidase, superoxide dismutase and phenylalanine ammonia lyase) was studied. Isozymes electrophoresis was carried out for two isozymes (peroxidase and polyphenol oxidase). New bands were detected which can be used as markers for gamma irradiation.
\end{abstract}

Keywords: Moringa oleifera, Gamma rays, Antioxidants, Isozymes.

\section{Introduction}

Moringa is a native tree in India, the Red Sea area and/or parts of Africa including Madagascar, however, it has been planted around the world and naturalized in many locales. Moringa has many names; in Philippines, where the leaves of the Moringa are cooked and fed to babies, it is called mother's best friend and malunggay. (Fahey, 2005).

All parts of the Moringa tree are edible and have long been consumed by humans. According to Fuglie (1999), the uses of Moringa include: animal forage (leaves and treated seed-cake), biogas (from leaves), blue dye (wood), fertilizer (seedcake), nutrient (juice expressed from the leaves), green manure (from leaves), honey (flower nectar), medicine (all plant parts), pulp (wood), tannin for tanning hides (bark and gum), water purification (powdered seeds).

Moringa leaves extracts showed an antioxidant effect with strong radical scavenging properties as cited by many researches (Sreelatha \& Padma,
2009 and Verma et al., 2009)

Antioxidants, whether natural or synthetic compounds have a role in inhibiting oxidation process and scavenge free radicals that play an important role in pathogenesis of several diseases, such as cancer, rheumatoid arthritis and cardiovascular diseases (Canadanovic et al., 2005). Moringa is a good source of phenolic compounds that have gained significant attention for their pharmacological properties, specially the antioxidant behavior and anti- inflammatory and anti-mutagenic activities (Rasika et al., 2011). Many reports detected a relation between the anticancer and antioxidant behavior of Moringa oleifera leaves and their contents from phenolic compounds (Khalafalla et al., 2010 and Charoensin, 2014), and the increase in the activity of some enzymes such as catalase (CAT) and superoxide dismutase (SOD).

Gamma rays have a short wavelength and therefore possess more energy per photon than X-rays. Cobalt-60 and Cesium-137 are the main

\#Corresponding author email: n.hamideldin@yahoo.com DOI: 10.21608/ejrsa.2018.2286.1035

C2018 National Information and Documentation Center (NIDOC) 
sources of gamma rays used in radiobiological work at present. At the level of medicinal plants studies, radiation is a good inducer for many useful improvements. Good results had been obtained at the level of germination, yield growth parameters and enhanced active ingredients (Mali et al., 2011; Silva et al., 2013 and Desal \& Rao, 2014).

The aim of the present study is to investigate the effect of different doses of gamma rays on the vegetative and physiological characters.

\section{Materials and Methods}

Seeds of Moringa oleifera were obtained from the Desert Research Center, Cairo, Egypt. Dry seeds of Moringa oleifera were exposed to different gamma rays doses $(0,20,40$ and 60Gy). Gamma irradiation was executed at the National Center for Radiation Research and Technology, Nasr City, Cairo, Egypt. Irradiation treatments were achieved using a ${ }^{60} \mathrm{Co}$ gamma unit (Indian gamma cell), which delivered 2.25kGy per hour at season 2014 and $1.98 \mathrm{kGy}$ per hour at season 2015 .

A batch from available seeds was kept without gamma irradiation to be used as control. The irradiated and non-irradiated seeds were soak in warm water for half hour to activate their germination and then were sown in plastic bags $(10 \times 20 \mathrm{~cm})$ each filled with $1 \mathrm{~kg}$ soil. The soil was a mixture of compost and sand as a rate of $1 / 3$ to $2 / 3$, respectively; with three replicates for each treatment contains 25 plastic bag with a rate of one grain/bag. The experiment was designed in a completely randomized experimental design.

\section{Vegetative characters}

After three months, five individual plants were taken from every replicate for each treatment and the control to determine the effect of gamma rays on the following vegetative characters: Stem height $(\mathrm{cm})$, stem diameter $(\mathrm{cm})$, number of branches/ plant, length of branches/plant $(\mathrm{cm})$, fresh leaves weight/plant $(\mathrm{g})$, fresh stem weight/plant $(\mathrm{g})$, fresh root weight/plant $(\mathrm{g})$, whole plant fresh weight (g), dry leaves weight/plant (g), dry stem weight/ plant (g), dry root weight/plant (g), whole plant dry weight $(\mathrm{g})$.

The previous field experiment was repeated in the next season to confirm the effect of gamma radiation on the studied traits.
Physiological analysis

Determination of total phenolic compounds (TPC)

The colorimetric method of Folin -Denis as described by Shahidi \& Naczk (1995) was used for the chemical determination of phenolic compounds in Moringa plants. Five replicates of leaf samples were used. A weight of fresh samples $(0.5 \mathrm{~g})$ was used to extract the phenolic compounds, they were determined by reading the developed blue color on spectrophotometer at $725 \mathrm{~nm}$ using one $\mathrm{ml}$ of $80 \%$ ethanol solution and reagent only as a blank. The corresponding amount of phenolic compounds was calculated from a standard solution prepared from pure pyrogallic acid (100ppm). The results were expressed as $\mathrm{g} / 100 \mathrm{~g}$ fresh weight.

\section{Amino acids content}

Amino acids analysis were done in amino acids laboratory, NCRRT according to the method of A.O.A.C (1990) after preparing the sample by weighing $100 \mathrm{mg}$ dry powdered sample in screw-capped glass tube containing $10 \mathrm{ml}$ of $6.0 \mathrm{~N}$ $\mathrm{HCl}$, the tubes were kept in an oven at $110^{\circ} \mathrm{C}$ for $24 \mathrm{~h}$ for complete digestion (Baxter, 1996). The system used for analysis was a high performance amino acid analyzer, Biochroma 20 (auto sampler version), Pharmacia Biotech at 56 NCRRT. Data analysis of chromatogram was performed using chromatography, Data System Tutorial and user's Guide-version 6.7.

\section{Enzymes activity assays \\ Enzymes extraction}

Frozen tissues of leaves $(0.5 \mathrm{~g})$ were ground using cold mortar and pestle and homogenized with cold sodium phosphate buffer $(100 \mathrm{mM}, \mathrm{pH}=7)$ containing $1 \%(\mathrm{w} / \mathrm{v})$ polyvinylpyrrolidone (PVP) and $0.1 \mathrm{mM}$ EDTA. The extraction ratio was $4 \mathrm{ml}$ extraction buffer for each $1 \mathrm{~g}$ of the plant tissues. The homogenate was centrifuged at $1200 \mathrm{rpm}$ at $4^{\circ} \mathrm{C}$ for $15 \mathrm{~min}$. The supernatant was used for measurement of different enzymes; catalase (CAT), polyphenol oxidase (PPO), peroxidase (POD) superoxide dismutase (SOD), and phenylalanine ammonia lyase (PAL) activities. Also, proteins concentration was quantified in the crude extract by the method of Lowry et al. (1951) using bovine serum albumin as a standard.

\section{Enzymes activity}

Polyphenol oxidase (PPO) assay

Polyphenol oxidase (EC 1.14.18.1) activity was measured according to Oktay et al. (1995). The 
reaction mixture contained $600 \mu \mathrm{l}$ catechol $(0.1 \mathrm{M})$ and $100 \mu 1$ enzyme extract was completed to $3.0 \mathrm{ml}$ with $0.1 \mathrm{M}$ phosphate buffer $\mathrm{pH} 7$. The absorbance was recorded at $420 \mathrm{~nm}$ by spectrophotometer (UVvisible-160A, Shimadzu).

\section{Peroxidase (POD) assay}

Peroxidase (EC1.11.1.7) activity was quantified by the method of Hammerschmidt et al. (1982). The assay mixture $(100 \mathrm{ml})$ contained $10 \mathrm{ml}$ of $1 \%(\mathrm{v} / \mathrm{v})$ guaiacol, $10 \mathrm{ml}$ of $0.3 \% \mathrm{H}_{2} \mathrm{O}_{2}$ and $80 \mathrm{ml}$ of $50 \mathrm{mM}$ phosphate buffer $(\mathrm{pH}=6.6)$. Volume of $100 \mu \mathrm{l}$ of crude enzyme was added to $2.9 \mathrm{ml}$ of the assay mixture to start the reaction. The absorbance was recorded every $30 \mathrm{sec}$ for $3 \mathrm{~min}$ at $470 \mathrm{~nm}$ using spectrophotometer (UV-Vis spectrophotometer UV 9100 B, Lab.Tech).

\section{Catalase (CAT) assay}

The activity of catalase (EC 1.11.1.6) was determined according to Aebi (1974). Enzyme extract $(100 \mu \mathrm{l})$ was added to $2.9 \mathrm{ml}$ of a reaction mixture containing $20 \mathrm{mM} \mathrm{H}_{2} \mathrm{O}_{2}$ and $50 \mathrm{mM}$ sodium phosphate buffer ( $\mathrm{pH} 7.0$ ). The activity of CAT was measured by monitoring the reduction in the absorbance at $240 \mathrm{~nm}$ as a result of $\mathrm{H}_{2} \mathrm{O}_{2}$ consumption. The amount of consumed $\mathrm{H}_{2} \mathrm{O}_{2}$ was calculated using a molar extinction coefficient of $0.04 \mathrm{~cm}^{2} \mu \mathrm{mol}^{-1}$.

\section{Phenylalanine ammonia lyase (PAL) assay}

The activity of phenylalanine ammonialyase (E.C 4.3.1.5) was determined as the rate of conversion of L-phenylalanine to trans-cinnamic acid according to the methods of $\mathrm{He}$ et al. (2001). PAL assay reaction mixture consisted of $100 \mu 1$ crude enzyme extract and $900 \mu \mathrm{l}$ of $6 \mu \mathrm{mol} \mathrm{L}$-phenylalanine in $500 \mathrm{~m}$ MTris- $\mathrm{HCl}$ buffer $(\mathrm{pH} 8.5)$. The mixture was incubated at $37^{\circ} \mathrm{C}$ for an hour, the enzymatic reactions stopped with $0.1 \mathrm{ml} 6 \mathrm{~N} \mathrm{HCl}$. The absorbance was measured using spectrophotometer (UV-visible-160A, Shimadzu) at 290nm.

\section{Superoxide dismutase (SOD) assay}

The activity of superoxide dismutase (EC 1.15.1.1) was assayed according to the method of Beauchamp \& Fridovich (1971) by measuring its ability as an enzyme to inhibit the photochemical reduction of nitro blue tetrazolium (NBT). A reaction mixture (3.0ml) containing $40 \mathrm{mM}$ phosphate buffer $(\mathrm{pH} 7.8), 13 \mathrm{mM}$ methionine, $75 \mu \mathrm{M}$ NBT, $2 \mu \mathrm{M}$ riboflavin, $0.1 \mathrm{mM}$ EDTA and $100 \mu$ of the crude enzyme extract was shaken and placed $30 \mathrm{~cm}$ below light source consisting of $15 \mathrm{~W}$ fluorescent lamp.
The absorbance was recorded at $560 \mathrm{~nm}$.

Native- polyacrylamide gel electrophoresis (Native $-P A G E)$

Native-polyacrylamide gel electrophoresis (Native-PAGE) was conducted to identify isozymes variation among studied cultivars using two isozymes systems according to Stegemann et al. (1985). Fresh and young leaf samples for irradiated and non-irradiated Moringa oleifera leaves $(0.5 \mathrm{~g})$ were used separately for isozymes extraction. The utilized isozymes were peroxidase (POD) and polyphenyl oxidase (PPO). The run was performed at 150 volt until the bromophenol blue dye has reached the separating gel and then the voltage was increased to 200volt .After electrophoresis, the gels were stained according to their enzyme systems with the appropriate substrate and chemical solutions, then incubated at room temperature in dark for complete staining.

\section{Statistical analysis}

The variation between the means of control and the three treatments (20,40 and 60Gy) were measured using Duncan's test (Waller \& Duncan, 1969)

\section{Results}

\section{Vegetative characters}

It was noticeable that the effect of $\gamma$-irradiation showed significant differences on the vegetative characters compared to the control either in the first or the second season (Table 1). The irradiated plants showed a significant increase for stem length when using 40 and 60Gy in the two seasons. The highest value for stem length was recorded at $60 \mathrm{~Gy}$ dose $(75.77 \mathrm{~cm})$ in the second season.

Both the number and length of branches showed increases through the two seasons with the three used doses. Branches number/plant scored the highest value in the two seasons at 60Gy dose $(9.0$ and $9.33 \mathrm{~cm}$, respectively), while branches length scored the highest value at $40 \mathrm{~Gy}$ dose $(24.30 \mathrm{~cm})$ in the second season compared with the control.

The weights of fresh and dried leaves showed significant increases with all doses in the two examined seasons. The same result was observed for the whole fresh and dry plant weights. At the first season, 40Gy dose recorded the highest value for whole fresh and dry plant weights (35.57 and $6.63 \mathrm{~g}$ ), respectively. 


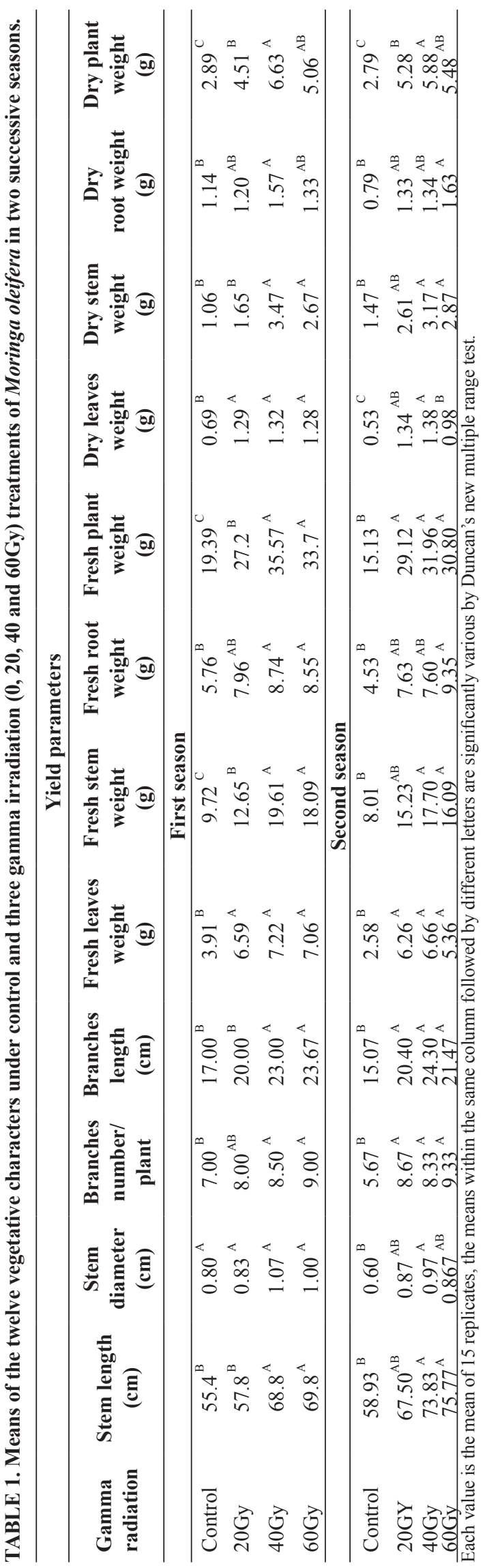

At the first season, the fresh and dry weights of stem for the irradiated plants showed significant increases with all doses, while they gave significant increases only at 40 and 60Gy and were insignificant at $20 \mathrm{~Gy}$ in the second season. The highest values for stem fresh and dry weights of 19.61 and $3.47 \mathrm{~g}$, respectively, were observed at $40 \mathrm{~Gy}$ in the first season. The weight of fresh roots for the irradiated plants showed significant increases at 40 and 60Gy doses in the first season and at 60Gy dose in the second season, while weight of dry roots showed a significant increase only at $40 \mathrm{~Gy}$ in the first season and at $60 \mathrm{~Gy}$ in the second season.

In general, the highest values for the studied traits were often observed at a dose of 40Gy (8 characters) then at a dose of 60Gy (4 characters).

\section{Physiological analysis \\ Total phenolic compounds (TPC)}

As shown in Table 2, the total phenols content (TPC) in Moringa oleifera leaves extraction was investigated for the irradiated and non-irradiated plants. The non-irradiated Moringa plants recorded $2.230 \mathrm{~g} / 100 \mathrm{~g}$ of phenolic content.

TABLE 2. Total phenolic content (TPC) under control and three gamma irradiation $(20,40$ and $60 \mathrm{~Gy})$ treatments of Moringa oleifera leaves.

\begin{tabular}{lccc}
\hline \multicolumn{4}{c}{ Phenols $(\mathrm{g} / \mathbf{1 0 0 g})$ F.W } \\
\hline Control & $\mathbf{2 0 G y}$ & $\mathbf{4 0 G y}$ & $\mathbf{6 0 G y}$ \\
$2.230^{\mathrm{c}}$ & $3.623^{\mathrm{AB}}$ & $4.062^{\mathrm{A}}$ & $3.525^{\mathrm{B}}$ \\
\hline
\end{tabular}

Each value is the mean of 5 replicates, different letters indicate a significant variation

The irradiated plants showed a significant increase of phenolic contents in the three used doses compared with the control. The 40Gy dose showed the highest value for TPC $(4.062 \mathrm{~g} / 100 \mathrm{~g})$ compared with the control and the other doses.

\section{Amino acid contents}

The amino acid profile analyses of Moringa leaves showed 17 amino acids ranged between $2.05 \mathrm{mg} / \mathrm{g}$ for cysteine and $36.24 \mathrm{mg} / \mathrm{g}$ for leucine for those untreated plants, with total amino acids $201.98 \mathrm{mg} / \mathrm{g}$. as shown in Table 3 .

In general, gamma radiation exhibited different effects on the amino acid content. The 20Gy dose scored the highest value in total amino acids content $(405.92 \mathrm{mg} / \mathrm{g})$ compared with the non-irradiated sample $(201.98 \mathrm{mg} / \mathrm{g})$, then 20 and $60 \mathrm{~Gy} 369.25$ and $220.77 \mathrm{mg} / \mathrm{g}$, respectively. 
TABLE 3. Amino acids profile under control and three gamma irradiation (20, 40 and $60 \mathrm{~Gy})$ treatments of Moringa oleifera leaves.

\begin{tabular}{|c|c|c|c|c|c|}
\hline \multicolumn{6}{|c|}{ Conc. mg/g D.W } \\
\hline No. & Amino acids & Control & $20 G y$ & $40 G y$ & 60Gy \\
\hline 1 & Asparticacid & 11.44 & 27.28 & 24.05 & 11.76 \\
\hline 2 & Threonine & 11.14 & 18.18 & 16.13 & 11.44 \\
\hline 3 & Serine & 9.97 & 17.30 & 15.84 & 10.26 \\
\hline 4 & Glutamic acid & 11.44 & 41.06 & 38.72 & 11.69 \\
\hline 5 & Proline & 4.10 & 68.29 & 55.97 & 8.66 \\
\hline 6 & Glycine & 8.50 & 20.24 & 20.53 & 8.50 \\
\hline 7 & Alanine & 7.62 & 23.46 & 22.58 & 8.84 \\
\hline 8 & Cysteine & 2.05 & 1.76 & 2.93 & 3.813 \\
\hline 9 & Valine & 9.97 & 16.13 & 15.25 & 9.97 \\
\hline 10 & Methionin & 7.64 & 7.62 & 8.21 & 13.01 \\
\hline 11 & Isoleucine & 11.22 & 13.49 & 12.90 & 10.26 \\
\hline 12 & Leucine & 36.24 & 29.33 & 26.98 & 36.05 \\
\hline 13 & Tyrosine & 13.49 & 24.64 & 22.58 & 15.17 \\
\hline 14 & Phenylalanine & 14.66 & 23.76 & 21.41 & 14.66 \\
\hline 15 & Histidine & 13.2 & 13.2 & 11.73 & 14.66 \\
\hline 16 & Lysine & 15.21 & 21.12 & 18.48 & 15.84 \\
\hline 17 & Arginine & 14.04 & 39.01 & 34.90 & 16.13 \\
\hline \multicolumn{2}{|c|}{ Total amino acids conc. $(\mathrm{mg} / \mathrm{g})$} & 201.98 & 405.92 & 369.25 & 220.77 \\
\hline
\end{tabular}

Most amino acids showed an increase with gamma ray doses, especially 20 and $40 \mathrm{~Gy}$, while 60Gy dose showed the amino acids concentration that is nearly consistent with the control samples.

Some amino acids such as aspartic, serine, glycine,valine, tyrosine and phenylalanine acid showed nearly double increase with both 20 and 40Gy compared with the control, while a slight increase was observed with the $60 \mathrm{~Gy}$ dose for the same amino acids.

On the other side, some amino acids such as glutamine, proline and alanine showed high increases at 20 and 40 Gy that reached three or four times the rate of the non-radiated samples and more than ten times at proline amino acid.

\section{Enzymes activity}

Five antioxidant enzymes activity were investigated for both the irradiated and nonirradiated (control) of Moringa oleifera leaves in two different stages of maturity (pre-flowering at 60 days age and post- flowering at 9 month age, approximately).
Polyphenol oxidase enzyme activity (PPO)

Polyphenol oxidase enzyme activity showed a vast difference between the two age stages of Moringa either for the irradiated or non-irradiated samples (Table 4).

At first, for pre-flowering stage, the irradiated samples showed an increase in the PPO activity of the control (2410.93unit/mg protein). This increase was significant at 40 and 60Gy (3878.6 and 3563.81), respectively while, 20Gy was insignificant (2715.45unit/mg protein).

In a similar manner, the increase in PPO activity was observed at post- flowering in the irradiated samples, the highest PPO activity value still achieved at 40Gy (12530.56unit/mg protein) compared with the control 8362.28unit/ mgprotein, then at 20 and $60 \mathrm{~Gy}$, the activities of PPO were 11115.73 and 8624.34 unit/mg protein, respectively.

\section{Peroxidase activity (POD)}

As shown in Table 4, the increase in POD activity was observed for the irradiated samples either pre or post - flowering compared to the corresponding non-irradiated (control) samples. 
TABLE 4. The difference in enzymatic activities of Moringa oleifera leaves for the five enzymes; PPO, POD, CAT, PAL and SOD under control and three gamma irradiation $(20,40$ and $60 \mathrm{~Gy})$ treatments of Moringa oleifera leaves for two maturing stages. (a)-At pre-flowering (60 days- old), (b)- Post- flowering (9 months)

\begin{tabular}{lccccc}
\hline $\begin{array}{l}\text { Gamma } \\
\text { radiation }\end{array}$ & $\begin{array}{c}\text { PPO } \\
\text { (unit/mg } \\
\text { protein) }\end{array}$ & $\begin{array}{c}\text { POD } \\
\text { (unit/mg protein) }\end{array}$ & $\begin{array}{c}\text { CAT } \\
\text { (unit/mg protein) }\end{array}$ & $\begin{array}{c}\text { PAL } \\
\text { (unit/mg protein) }\end{array}$ & $\begin{array}{c}\text { SOD } \\
\text { (unit/mg protein) }\end{array}$ \\
\hline \multicolumn{5}{c}{ a- Pre- flowering stage } \\
\hline Control & $2410.93^{\mathrm{B}}$ & $10.510^{\mathrm{B}}$ & $0.420^{\mathrm{B}}$ & $0.636^{\mathrm{B}}$ & $9.150^{\mathrm{B}}$ \\
$20 \mathrm{~Gy}$ & $2715.45^{\mathrm{B}}$ & $12.522^{\mathrm{B}}$ & $0.550^{\mathrm{B}}$ & $0.939^{\mathrm{A}}$ & $10.767^{\mathrm{A}}$ \\
$40 \mathrm{~Gy}$ & $3878.6^{\mathrm{A}}$ & $19.585^{\mathrm{A}}$ & $1.184^{\mathrm{A}}$ & $1.396^{\mathrm{A}}$ & $10.667^{\mathrm{A}}$ \\
$60 \mathrm{~Gy}$ & $3563.81^{\mathrm{A}}$ & $17.398^{\mathrm{A}}$ & $0.561^{\mathrm{B}}$ & $0.827^{\mathrm{A}}$ & $10.879^{\mathrm{A}}$ \\
\hline \multicolumn{5}{c}{ b- Post- flowering stage } & \\
\hline Control & $8362.28^{\mathrm{B}}$ & $19.502^{\mathrm{B}}$ & $2.262^{\mathrm{C}}$ & $0.638^{\mathrm{B}}$ & $10.914^{\mathrm{B}}$ \\
$20 \mathrm{~Gy}$ & $11115.73^{\mathrm{A}}$ & $22.401^{\mathrm{A}}$ & $3.841^{\mathrm{AB}}$ & $0.999^{\mathrm{A}}$ & $13.945^{\mathrm{A}}$ \\
$40 \mathrm{~Gy}$ & $12530.56^{\mathrm{A}}$ & $24.387^{\mathrm{A}}$ & $5.142^{\mathrm{A}}$ & $1.183^{\mathrm{A}}$ & $14.530^{\mathrm{A}}$ \\
$60 \mathrm{~Gy}$ & $8624.34^{\mathrm{B}}$ & $19.410^{\mathrm{B}}$ & $3.575^{\mathrm{B}}$ & $0.868^{\mathrm{AB}}$ & $12.109^{\mathrm{AB}}$ \\
\hline
\end{tabular}

Each value is the mean of 5 replicates; the means within the same column followed by different letters are significantly various by Duncan's new multiple range test

At pre-flowering stage, a significant increase of POD activity was found at 40 and 60Gy, while the increase in POD activity at 20Gy was insignificant. The highest significant values were scored at 40 and 60Gy (19.585 and 17.398 unit/mg protein) respectively compared with the corresponding non-irradiated samples (10.510unit/ mg protein), while applying 20Gy dose exhibited insignificant POD activity compared with the control (Table 4).

On the other side, after the flowering stage, the POD activity showed significant increases at 20 and 40Gy, while the activity at 60Gy was convergent to which observed at the corresponding control sample. The highest values still scored at 40Gy (24.387unit/mg protein) compared with the corresponding non-irradiated sample (19.502unit/ $\mathrm{mg}$ protein), then at 20 and 60Gy, they were 22.401 and 19.410 , respectively.

\section{Catalase activity (CAT)}

As shown in Table 4, at the pre-flowering stage, a significant increase for CAT activity was found using 40Gy (1.184unit/mg protein), while the increases in the CAT activity at 20 and 60Gy were insignificance $(0.550$ and $0.561 \mathrm{unit} / \mathrm{mg}$ protein, respectively), compared with the corresponding non-irradiated samples ( $0.420 \mathrm{unit} / \mathrm{mg}$ protein).

At the same time, after the flowering stage, all the used doses showed significant increases for the CAT activity compared to the non-irradiated samples. The highest values still achieved at 40Gy (5.142unit/mg protein) compared with the corresponding non-irradiated samples (2.262 unit/ $\mathrm{mg}$ protein), while 20 and $60 \mathrm{~Gy}$ showed 3.841 and 3.575 , respectively.

Phenylalanine ammonia-lyase activity (PAL)

Phenylalanine ammonia-lyase activity (PAL) is the key enzyme for the metabolism of phenols. It catalyzes the deamination of L-phenylalanine to yield ammonia and trans-cinnamic acid from which phenolic compounds are produced. As shown in Table 4, the PAL activity showed the same values for the non-irradiated samples at both the two stages; pre and post flowering $(0.636,0.638$ unit/ $\mathrm{mg}$ protein, respectively). At the age 60 days (preflowering), a significant increase was observed for the PAL activity at 20 and 40Gy doses, while the increase at $60 \mathrm{~Gy}$ was insignificant, the same result was observed for the value of post-flowering stage. The 40Gy recorded the highest value for the PAL activity compared to the corresponding control and other gamma doses within the two stages (1.396, $1.183 \mathrm{unit} / \mathrm{mg}$ protein) for pre and post- flowering, respectively.

It is worthy to note that the significant increase in the PAL activity at both 20 and 40Gy doses explains the significant increase in the total phenolic content at the same doses as shown in Table 4.

\section{Superoxide dismutase (SOD)}

As shown in Table 4, the increase in the SOD activity was observed for the irradiated samples either pre or post-flowering compared to the corresponding non-irradiated samples. At the preflowering stage, asignificant increase in thePOD 
activity was found while applying three used doses (10.767, 10.667 and 10.879unit/mg protein) compared with the corresponding non-irradiated samples (9.150unit/mg protein).

On the other side, after the flowering stage, the SOD activity showed significant increases at 20 and 40Gy, while at 60Gy no significant increase was observed. The highest value was shown at 40Gy (14.530unit/mg protein).

\section{Electrophoretic analysis of isozymes}

Isozymes electrophoretic technique was applied to study the differences in isozymes patterns for both PPO and POD antioxidant enzymes in Moringa oleifera leaves under the non-irradiated and irradiated treatments at two different stages of maturity (pre-flowering at age of 60 days and post- flowering at age of nine months).

\section{Polyphenoloxidase (PPO) isozymes}

The electrophoretic pattern and diagram of polyphenoloxidase (PPO) isozymes are illustrated in Fig. 1.

The differences between the non-irradiated (control) and irradiated samples are shown for both the presence and intensity of bands. At preflowering stage, the control samples exhibited only one band with moderate intensity. The effect of gamma irradiation showed polymorphism differences between doses. Both 40 and 60Gy doses showed increases in the bands number and intensity compared with the control, while 20Gy did not show a difference when compared to the

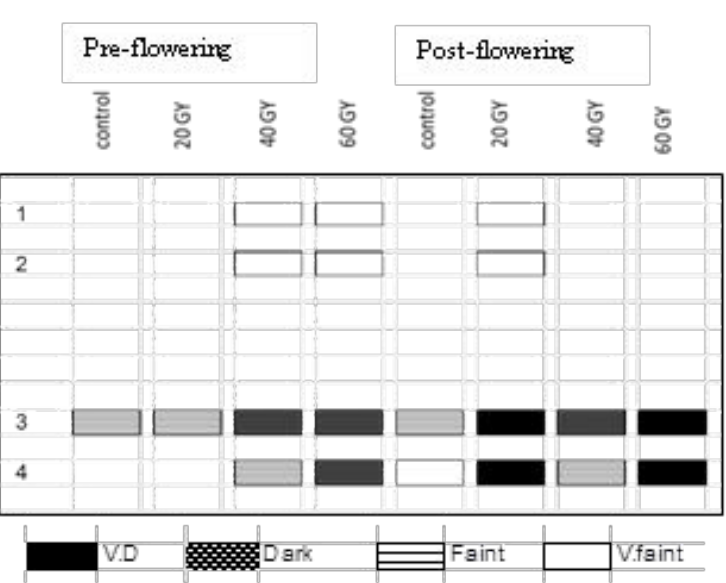

control. Four bands with different intensities (between very faint and dark intensities) were found at $40 \mathrm{~Gy}$ and $60 \mathrm{~Gy}$ doses.

At post- flowering stage, the non-irradiated sample exhibited two bands with very faint and moderate intensities, 20Gy showed obvious increases in the band number (bands no. 1 and 2) and intensity compared with the corresponding control. The third and fourth bands were detected in all samples, while the irradiated samples showed high intensities (dark and very dark) for these two bands compared with the control, as shown in Fig. 1.

Consequently, the first, second and fourth bands were positive markers for 40 and 60Gy doses at the pre-flowering stage, while, the first and the second bands were positive markers for only $20 \mathrm{~Gy}$ dose at post-flowering stage.

\section{Peroxidase (POD) isozymes}

The electrophoretic pattern and diagram of peroxidase isozymes are illustrated in Fig. 2. Gamma irradiation effects appeared on both bands numbers and intensity as shown in Fig. 2. At the pre-flowering stage, the non-irradiated samples and 20Gy dose irradiated samples exhibited two bands (1 and 3) with faint and dark intensities. The effect of gamma irradiation was clear at both 40 and 60Gy that showed increases in bands number 2 and 4 and intensity compared with the non-irradiated (control) samples that the second and fourth bands are positive markers at the 40 and 60Gy doses.

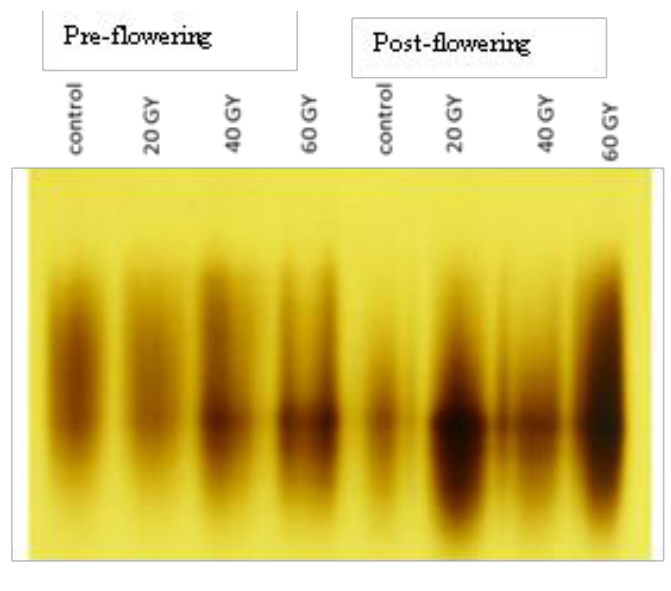

Fig. 1. Polyphenols oxidase isozymes banding patterns under control and three gamma irradiation (20, 40 and $60 \mathrm{~Gy}$ ) treatments of Moringa oleifera leaves at two maturity stages. 


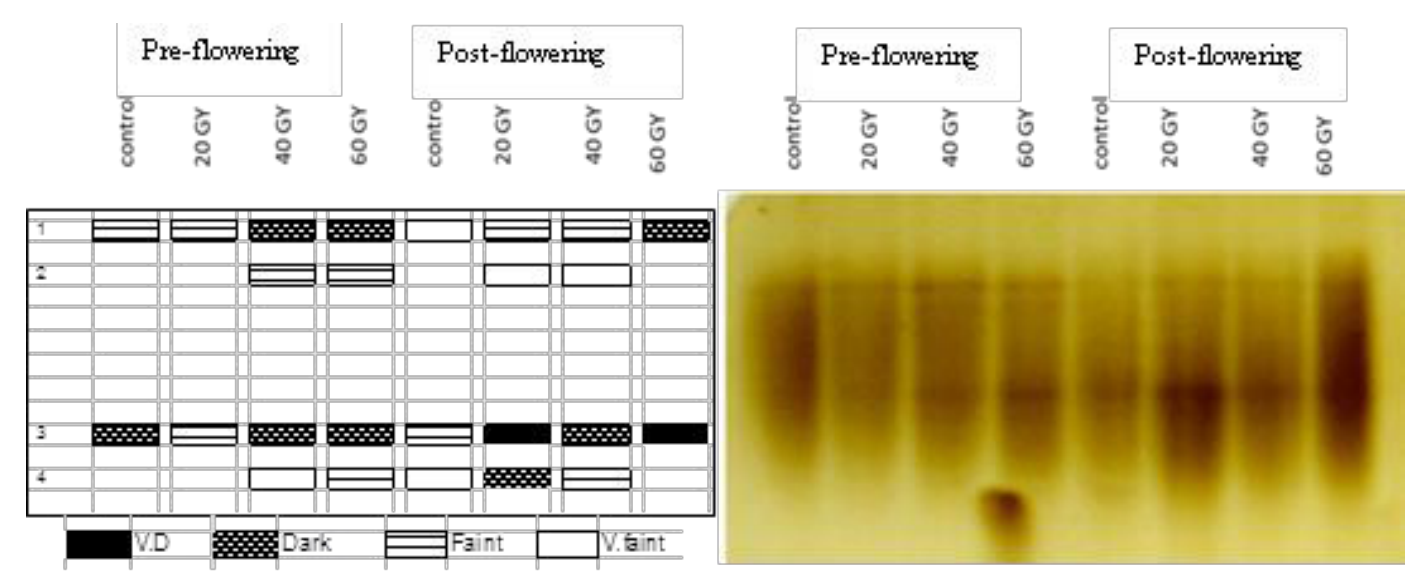

Fig. 2. Peroxidase isozymes banding patterns under control and three gamma irradiation (20, 40 and $60 \mathrm{~Gy})$ treatments of Moringa oleifera leaves.

At the post-flowering stage, the non-irradiated samples exhibited three bands with a relatively faint and very faint intensities, gamma irradiation showed changes in either bands number or intensity.Both 20 and 40Gy showed increases in band numbers (four bands) and intensities (very faint, faint, dark and very dark) compared with the corresponding control samples. The 60Gy dose showed superiority for bands intensity compared with the corresponding control, two bands were detected with dark and very dark intensities as shown in Fig. 2. The second band is a positive marker for both 20 and 40Gy gamma doses.

It is worth noting that these results confirm the results of the enzymes activity for both PPO and POD which were previously obtained, for example; the significant increases in the PPO activity that was observed at the 40 and 60Gy doses of the irradiated samples in the pre-flowering stage was associated withthe increases in bands number and intensity compared with the corresponding non-irradiated samples. In the same trend, at the post- flowering stage, both 20 and 40Gy recorded significant increases in the PPO activity which was associated with the increases in the numbers and intensity of isozymes bands compared with the corresponding non-irradiated samples.

The same observation can be recorded for the POD enzyme. The significant increase in the POD activity that wasobserved at the 40 and $60 \mathrm{GY}$ doses of the irradiated samples in the preflowering stage was associated with the increases in band numbers and intensity compared with the corresponding non-irradiated samples. Moreover, similar observations were recorded with both 20 and 40Gy doses compared with the corresponding control at the post- flowering stage. Therefore, the increase in the gene expression for the isozymes patterns was related to the significant increase in the activities of both enzymes.

\section{Discussion}

Gamma irradiation enhances all the studied vegetative characters, this enhancement effect of gamma radiation was in harmony with that found by Hamideldin \& Eliwa (2015) and Hussein \& Hamideldin (2016) who reported significant increases of some traits as plant height, branches and leaf number, fresh and dry weights of root and root length using low doses of gamma irradiation.

Gamma irradiation induces significant increases in phenols contents in the three used doses, similar results were obtained by El Sohaimy et al. (2015), while showed dissimilarity with Sreelatha \& Padma (2009).

The increase in the phenolics content was also in agreement with the results of Taheri et al. (2014) on Curcuma and Mali et al. (2011) on Pomegranate.

This increase in the total phenols is related to activity of L-phenylalanine ammonia-lyase (PAL) enzyme, many reports emphasize the correlation between the increase in the corresponding PAL gene/protein expression/activity and the increase in the phenolic compounds in responses to different stimuli (Boudet, 2007). 
Moringa leaves were rich in essential amino acids such as leucine, lysine, phenylalanine and histidine and non-essential amino acids such as tryrosine, arginine and aspartic acid. Among the essential amino acids, leucine was the highest in Moringa leaves.

Among the essential amino acids, leucine was the highest in Moringa leaves; this is in harmony with that reported by Okereke \& Akaninwor (2013).

In general, gamma irradiation showed a positive effect on the amino acids of Moringa leaves that was in harmony with that found by Hussein \& Hamideldin (2016), who observed increases in all the analyzed amino acid contents of Sesamum indicum L. seeds using low doses of gamma radiation (30 and 60Gy).

On the other side, these results were different with from those found by Bamidele \& Akanbi (2015), who found a negative effect of gamma rays on amino acid in pigeon pea when using the highest doses from radiation (5-20kGy) and Ahsan et al. (2013) who studied the effect of gamma radiation on the amino acid composition of Oryza sativa L., they reported that no change occurred in the amino acid composition of the irradiated samples when compared to the control samples (non-irradiated) using 2,4 and $6 \mathrm{kGy}$ doses.

In the same context, the effect of gamma radiation on the number of antioxidant enzymes was studied by Kebeish et al. (2015) who found a significant increase in the activity of the PPO enzyme when using a low level of gamma radiation.

These results are in harmony with those reported by Shen et al. (2010) who found that a low dose of gamma radiation activated and stimulated the peroxidase activity and affected the peroxidase's isozymatic composition. Similarly, Sreedhar et al. (2013) found a variable degrees of stimulation in the activities of POD in leaves of groundnut (Arachis hypogaea L.) irradiated with various doses of gamma rays.

The increase in the activity of CAT enzyme using gamma radiation was similar to that found by Kebeish et al., (2015) who found gradual increase in the CAT activity in Allium sativum L. with increasing the level of $\gamma$ - radiation up to 100Gy, while it was different to that reported by Al-Rumaih
\& Al-Rumaih (2008) who found a decrease in the CAT activity in the shoots and root of three species of Trigonella with gamma radiation.

At the same trend, a positive correlation was observed between the PAL activity, total phenolics and total flavonoids by Nadernejad et al. (2012) in the leaves of Pistacia vera $\mathrm{L}$. The enhancement in the PAL activity using gamma radiation was in harmony with that observed by Benoit et al. (2000), who found that an increase in the PAL activity using gamma irradiation was associated with the increase in thetotal phenols concentration in edible mature mushrooms (Agaricus bisporus).

The observed influence of gamma radiation on the activity of the SOD enzyme was in harmony with that reported by Al-Rumaih \& Al-Rumaih (2008) who found that different doses of gamma radiation increased the activity of the SOD enzyme in the shoots and root of three species of Trigonella. In the same context, Sreedhar et al. (2013) found a significant increase in the activity of the SOD enzyme in the leaves of Arachis hypogaea L., using different doses of gamma radiation (10:100Gy).

The results of the effect of gamma rays on isozymes pattern of both PPO and POD are in agreement with those reported by Hamideldin et al. (2017) who found differences in isozymes patterns of both PPO and POD in both bands number and intensity using different doses of gamma irradiation.

\section{Conclusion}

Gamma radiation $(\leq 60 \mathrm{~Gy})$ can be used to improve vegetative and physiological characters in the Moringa olifera leaves. The new bands detected in isozymes electrophoresis of peroxidase and polyphenol oxidase can be used as markers for gamma irradiation.

\section{$\underline{\text { References }}$}

Aebi, H. (1974) In: "Methods of Enzymatic Analysis. Catalase". Bergmeyer, H.U. (Ed.). Verlag Chemie/ Academic Press Inc., Weinheim/NewYork, USA. 680p.

Ahsan, S., Hussain, Z., Naqvi, S.A.R. and Asi, M.R. (2013) Effect of gamma radiation on aflatoxin load, amino acid and fatty acid composition of Oryza sativa L. Pak. J. Bot. 45(5), 1577-1580.

Al-Rumaih, M.M. and Al-Rumaih, M.M.

(2008) 
Influence of ionizing radiation on antioxidant enzymes in three species of Trigonella. Americ. $J$. Environ. Sci. 4(2), 151-156.

AOAC Association of official Chemists (1990) "Official Methods of Analysis", $16^{\text {th }}$ ed. Association of Official Analytical Chemists Washington, DC.

Bamidele, O.P. and Akanbi, C.T. (2015).Effect of gamma irradiation on amino acids profile, minerals and some vitamins content in pigeon pea (Cajanus cajan) Flour. British J. Appl. Sci. Technol. 5(1), 90-98.

Baxter, J.H. (1996) Amino Acids. In: "Handbook of Food Analysis", pp.179-228, $1^{\text {st }}$ ed. Nollet, L.M.L.

Beauchamp, C. and Fridovich, I. (1971) Superoxide dismutase: Improved assays and an assay applicable to acrylamide gels. Anal.Biochem. 44, 276-287.

Benoît, M.A, D’Aprano, G. and Lacroix, M. (2000) Effect of gamma-irradiation on phenylalanine ammonia-lyase activity, total phenolic content and respiration of mushrooms (Agaricus bisporus). J. Agric Food Chem. 48(12), 6312-6316.

Boudet, A.M. (2007) Evolution and current status of research in phenolic compounds. Phytochemist. 68, 2722-2735.

Canadanovic, B.J.M., Djilas, S.M. and Cetkovic, G.S. (2005) Free-radical scavenging activity of worm wood (Artemisia absinthium) extracts. J. Sci. Food Agric. 85, 265-272.

Charoensin, S. (2014) Antioxidant and anticancer activities of Moringa oleifera leaves. J. Med. Plants Res. 8(7), 318-325.

Desal, A.S. and Rao, S. (2014) Effect of gamma radiation on germination and physiological aspects of pigeon pea (Cajanus cajan (L.) millsp) seedlings. Inter. J. Appl. Res. 2(6), 47-52.

El Sohaimy, S.A., Hamad, G.M., Mohamed, S.E., Amar, M.H. and Al-Hindi, R.R. (2015) Biochemical and functional properties of Moringa oleifera leaves and their potential as a functional food.Glo. Adv. Res. J. Agric. Sci. 4(4), 188-199.

Fahey, J.W. (2005) Moringa oleifera: A review of the medical evidence for its nutritional, therapeutic, and prophylactic properties. Part 1. Trees Life J. 1, 1-15.

Fuglie, L.J. (1999) "The Miracle Tree: Moringa oleifera: Natural Nutrition for the Tropics". Church World Service, Dakar. 68. The Multiple Attributes of Moringa, pp.103-115.

Hamideldin, N. and Eliwa, N.E. (2015) Gamma radiation and sodium azide influence on physiological aspects of maize under drought condition. Basic Rese. J.
Agric. Scie. Review, 4(1), 5-13.

Hamideldin, N., Eliwa, N.E. and Hussein, O.S. (2017) Role of jasmonic acid and gamma radiation in alleviating salt stress in moringa. Int. J. Agric. Biol. 19, 93-98.

Hammerschmidt, R., Nuckles, E. and Kuc, J. (1982) Association of enhanced peroxidase activity with induced systemic resistance of cucumber to Colletotrichum lagenarium. Physiol. Plant Pathol. 20, 73-82.

He, C.Y., Hsiang, T. and Wolyn, D.J. (2001) Activation of defense responses to Fusarium infection in Asparagus densiflorus. Euro. J. Plant Pathol. 107, 473-483.

Hussein, O.S. and Hamideldin, N. (2016) Influence of pre-sowing treatments by gamma rays on growth, yield and some chemical constituents of Sesamum indicum L. Grasasy Aceites, 67(1), 1-6.

Kebeish , R., Deef, H.E. and El-Bialy, N. (2015) Effect of gamma radiation on growth, oxidative stress, antioxidant system, and alliin producing gene transcripts in Allium sativum. Inter. J. Res. Stud. Bioscie. (IJRSB), 3(3), 161-174.

Khalafalla, M.M., Abdellatef, E., Dafalla, H.M., Nassrallah, A.A., Aboul-Enein, K.M., Lightfoot, D.A., El-Deeb, F.E. and El-Shemy, H.A. (2010) Active principle from Moringa oleifera Lam leaves effective against two leukemias and a hepatocarcinoma. Afr. J. Biotechnol. 9(49), $8467-$ 8471.

Lowry, O.H., Rosebrough, N.J., Farr, A.L. and Randal, R.J. (1951) Protein measurement with the folin phenol reagent. J. Biol. Chem. 193, 265-275.

Mali, A.B., Khedkar, K. and Lele, S.S. (2011) Effect of gamma irradiation on total phenlic content and in vitro antioxidant activity of pomegranate (Punica granatum L.) peels. Food Nutri. Sci. 2, 428-433.

Nadernejad, N., Ahmadimoghadam, A., Hosseinifard, J. and Pourseyedi, S. (2012) Phenylalanin ammonialyase activity, total phenolic and flavonoid content in flowers, leaves, hulls and kernels of three Pistachio (Pistacia vera L.) cultivars. American-Eurasian J. Agric. \& Environ. Sci. 12(6), 807-814. 
Okereke, C.J. and Akaninwor, J.O. (2013) The protein quality of raw leaf, seed and root of Moringa oleifera grown in rivers state, Nigeria. Ann. Biolo. Rese. 4, (11), 34-38.

Oktay, M., Kufrevioğlu, O.I., Kocacaliskan, I. and Sakiroğlu, H. (1995) Polyphenol oxidase from Amasya apple. J. Food Sci. 60, 495-499.

Rasika, C.T., Lavate, S.M. and Jadhavi, R.B. (2011) Evaluation of phenol and flavonoid content from aerial parts of Tecomastans. Inter. J. Pharma. Pharma. Scie. 34(32), 126-127.

Shahidi, F. and Naczk, M. (1995) Methods of analysis and quantification of phenolic compounds. In: "Food Phenolic: Sources, Chemistry, Effects and Applications", pp. 287-293. Technomic Publishind Company, Inc: Lancaster.

Shen, X., Li, X., Li, Z., Li, J., Duan, L. and Eneji, A.E. (2010) Growth, physiological attributes and antioxidant enzyme activities in soybean seedlings treated with or without silicon under UV-B radiation stress. J. Agron. Crop Sci. 196(6), 431-439.

Silva, T.M., Miranda, R.R.S., Ferraz, V.P., Pereira, M.T., de Seiqueira, E.P. and Alcantara, A.F.C. (2013) Changes in the essential oil composition of leaves of Echinodorus macrophyllus exposed to $\gamma$ - radiation. Brazi. J.Pharma. 23(4), 600-607.
Sreedhar, M., Chaturvedi, A., Aparna, M., Pavan, K.D., Singhal, R.K. and Venu-Babu, P. (2013)Influence of $\gamma$-radiation stress on scavenging enzyme activity and cell ultra-structure in groundnut (Arachis hypogaea L.). App. Scie. Rese. 4(2), 35-44.

Sreelatha, S. and Padma, P.R. (2009) Antioxidant activity and total phenolic content of Moringa oleifera Leaves in two stages of maturity. Plant Foods Hum. Nutr. 64, 303-311.

Stegemann, H.A., Afify, M.R. and Hussein, K.R.F. (1985) $2^{\text {nd }}$ International Symposium of biochemical approaches to identification of cultivars. West Germany (Braunschweig), pp. 44

Taheri, S., Abdullah, T.L., Karimi, E., Oskoueian, E. and Ebrahimi, M. (2014) Antioxidant capacities and total phenolic contents enhancement with acute gamma irradiation in Curcuma alismatifolia (Zingiberaceae) leaves. Int. J. Mol. Sci. 15(7), 13077-13090.

Verma, A.R., Vijayakumar, M., Mathela, C.S. and Rao, C.V. (2009) In vitro and in vivo antioxidant properties of different fractions of Moringa oleifera leaves. Food Chem. Toxicol. 47, 2196-2201.

Waller, R.A. and Duncan, D.B. (1969) Am. Stat. Assoc. J. 1485-1503.

(Received 11/12/2017; accepted 13/5/2018) 


\section{دراسات فسيولوجية ووراثية لتاثير التشعيع الجامى على المورينجا}

حنان محمد منصور (1)، نهله حميد الدين (1)، فتحى محمدعبد التواب (2)، ايمان محمود فهمى (2)، هدى (1) في

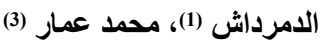

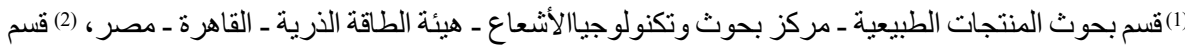

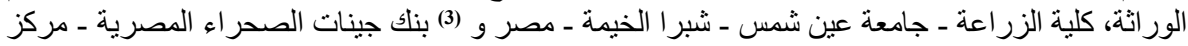

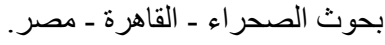

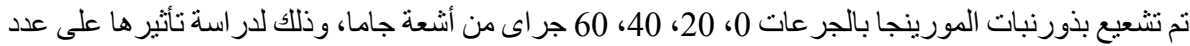

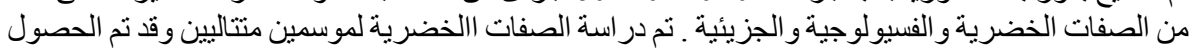

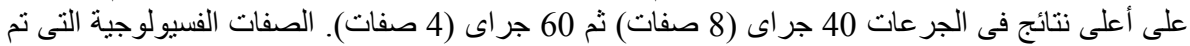

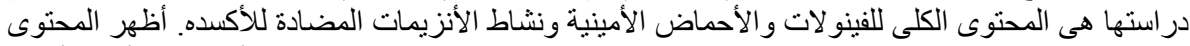

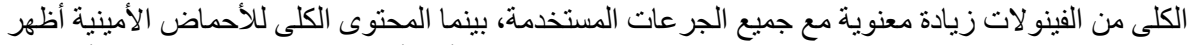

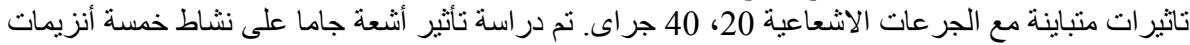

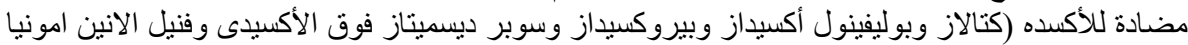

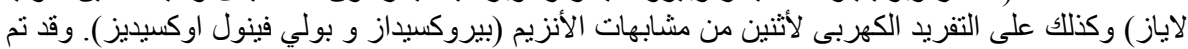

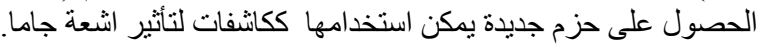

